\section{Measurements of landscape capacity for water detention and wetland restoration practices can inform watershed planning goals and implementation strategies}

\author{
M.D. Tomer and J.A. Nelson
}

\begin{abstract}
Increases in the frequency of floods are leading watershed planners to encourage practices that can attenuate surface runoff. Water detention practices that are distributed watershed wide are one approach being considered. Several water detention practices also provide wetlands that carry habitat and water quality benefits. How should planners set planning goals to realize these benefits? This editorial examines how precision siting of practices can provide data for evaluating watershed goals and assessing how implementation strategies may influence chances of success in reaching those goals. In three HUC12 watersheds representing different landscape regions of Minnesota's Yellow Medicine River, the Agricultural Conservation Planning Framework (ACPF) toolbox was used to locate sites suited for installation of water and sediment control basins (WASCOBs), depressional (prairie pothole) wetlands, and nutrient removal wetlands. Tabulated attributes for sited practices included water storage capacities (volume) and potential wetland areas, which were summed to represent a "landscape capacity" for storing water and creating wetlands in each watershed. These capacities were plotted with interim (10-year) watershed planning goals established for water storage and new wetland areas, and progress toward reaching these goals was estimated assuming implementation of 30 wetland practices, selected either at random or by rank when prioritizing sites based on water storage volume, wetland size, or runoff-contributing area. Results indicated that a random ranking could be effective in reaching at least one interim (10-year) planning goal in each watershed. Results show ACPF watershed planning products can be used to evaluate planning goals and whether recruitment strategies for implementation need to target larger, priority sites to ensure success. The question is important because targeted recruitment of a few large sites that may optimize benefits may also be difficult to implement for social and/or logistical reasons. Whereas, if open enrollment strategies can be successful over interim planning windows, they can also demonstrate new practices to enhance social acceptance for broadening future conservation benefits. Results suggest an avenue for collaborative landscape-scale agricultural research crossing social and conservation disciplines.
\end{abstract}

Key words: Agricultural Conservation Planning Framework-conservation practices-water storage-watershed planning-wetlands
Flood mitigation is a growing concern throughout the Midwest and Great Plains. Multiple tributaries within the Mississippi River Basin have broken records for flooding in the last decade, and a 2019 federal disaster package of US $\$ 17.2$ billion has become law (US Congress 2019).
Substantial risks to levee infrastructure due to increased flooding in the upper Midwest have been identified by the US Army Corps of Engineers. Eleven levees were breached along the Upper Mississippi River in Iowa, Illinois, and Missouri during 2019. Additionally, six levees found at high risk of
Received June 21, 2019; Revised December 20, 2019; Accepted January 20, 2020; Published online April 25, 2020. failure are now providing scant protection for 1.8 million people and properties valued at US\$31.2 billion (Environmental Law and Policy Center 2019). Yet, elevating levee heights to mitigate floods can increase the risk of catastrophic damage from overtopping during extreme events (Di Baldassarre et al. 2013) and can increase flood damage upstream of levees (Heine and Pinter 2012). Therefore, with increasing impacts of more frequent high-intensity storms (Hatfield et al. 2013), levees can only be part of an approach to manage flooding in the Midwest.

Mitigation of flood risks can be achieved in several ways in addition to levee construction, including (1) use of agricultural practices (e.g., restricted tillage and diversified cropping systems) that attenuate runoff by increasing infiltration (Tomer et al. 2005; Karlen et al. 2009); (2) floodplain reconnection, which allows selected areas of floodplains to be inundated during high flows (Opperman et al. 2009); and (3) increasing water detention in uplands using impoundments (Ayalew et al. 2015; Thomas et al. 2016) and wetland restoration (or creation) practices (McAllister et al. 2000). Among these options, water storage above low $(<10 \mathrm{~m})$ impoundments and wetlands are key practices for detaining runoff within headwater areas found above floodplains. Several studies in the Midwest have evaluated this watershed-based approach to flood attenuation. Model simulations show that water storage capacities of wetland restorations could reduce peak discharge of design-storm-event simulations in central Indiana (Babbar-Sebens et al. 2013) and northern Iowa (Thomas et al. 2016) watersheds. In southeast Iowa, the presence of 144 farm pond impoundments in Soap Creek watershed $\left(660 \mathrm{~km}^{2}\right)$ attenuated peak flows simulated for a range of rainfall amounts (Ayalew et al. 2017). Reported reductions in simulated peak flows among these modeling studies depend on antecedent conditions and practice-placement scenarios being evaluated, but range to $>30 \%$. Modeling work has further shown that distributing water detention

Mark D. Tomer is a research soil scientist for USDA Agricultural Research Service National Laboratory for Agriculture and the Environment, Ames, lowa. Jessica A. Nelson (corresponding author) is a graduate research assistant with lowa State University Department of Agronomy, Ames, lowa, and formerly a GIS specialist with Water Resources Center, Minnesota State University, Mankato, Minnesota. 
structures among headwater subbasins can provide greater benefits for peak flow attenuation than by placing multiple structures in series along a stream, or by placing a single large impoundment near the watershed outlet (Ayalew et al. 2015). Similarly, Babbar-Sebens et al. (2013) concluded that distributing small wetlands in a watershed could be effective in attenuating peak flows. These modeling studies show that the distribution of multiple small water storage structures and/or wetlands across a watershed may be a valid approach to attenuate runoff and mitigate risks of flooding. However, opportunities to install impoundments and wetlands to store runoff water will vary among watersheds. This editorial explores the characterization of water detention and wetland restoration capacities at a small-watershed scale as an input to inform watershed planning within a Midwest river basin.

\section{The Agricultural Conservation Planning Framework and Water Detention Practices}

High resolution data sources now offer opportunities to characterize soil and water conservation opportunities within watersheds at a level of precision that can be used for farm- and field-scale planning (Tomer et al. 2013). The Agricultural Conservation Planning Framework (ACPF) provides databases (Tomer et al. 2017) and geographic analysis tools (Porter et al. 2018) to help visualize a full suite of agricultural conservation practices that could be placed in a small (i.e., 4,000 to $16,000 \mathrm{ha}$ ) watershed (Tomer et al. 2015). Publicly available USDA data on soil survey and crop cover are summarized at field scale, providing watershed databases (Tomer et al. 2017) that are analyzed together with high-resolution (2 to $3 \mathrm{~m}$ grid) digital elevation models (DEMs) to identify placement options for a variety of in-field, edge-of-field, and riparian practices that can reduce runoff and improve water quality (Porter et al.2018). Conservation options are specific enough for planners to engage landowners in visualizing future conservation scenarios on their farms (Ranjan et al. 2020), and the ACPF is being used in an increasing number of watersheds. Conservation planning field staff have used ACPF results in watershed planning and producer engagement in several Minnesota watersheds (Dakota County SWCD 2016). In eastern Iowa, maps of existing conservation practices have been cross-referenced with ACPF results to evaluate opportunities for implementation and progress in meeting nutrient reduction goals (Rundhaug et al. 2018). In a central Iowa watershed, Zimmerman et al. (2019) extended ACPF results to include assessments of nitrogen $(\mathrm{N})$ leaching potential with opportunity costs of land conversion to conservation cover to derive an economically optimized scenario to achieve targeted reductions in $\mathrm{N}$ loss Gesch et al. (2020) describe ACPF use and farmer engagement in the watershed planning process being used by the Iowa Soybean Association. The ACPF results provide data for watershed-scale planning by identifying candidate sites for conservation practices. The candidate sites can be ranked using data provided in attribute tables, but field verification and engineering design is necessary for actual design and construction of practices.

Several water storage practices can be sited by the ACPF including water and sediment control basins (WASCOBs), and wetland creation and restoration practices. As will be described, the ACPF tools that site possible locations for WASCOBs and wetland creations are based on use of low impoundments, whereas, wetland restorations are suggested in topographic depressions (i.e., prairie potholes). Estimated pool areas, water-storage volumes, and contributing (treated) area can be obtained for each suggested practice location from results of the ACPF. The volume and area attributes may be ranked by site to prioritize among sites, and may be summed by watershed to estimate "landscape capacities" for increasing water storage and wetland habitat using specific practices. This information may help planners prioritize conservation practices and implementation efforts. Because water detention and wetland practice locations identified by the ACPF can be ranked, implementation strategies may be based on different prioritization rankings, or alternatively, may use a nonprioritized, open engagement approach. A nonprioritized approach can help to "cast a wide net" that enables early adopters to implement and demonstrate new practices, which can help landowners more clearly visualize new practices for water detention on the local landscape.

This editorial has three objectives. We first show that landscape capacities for water storage and wetland development can be developed for a watershed, based on ACPF results that provide an inventory of locations where specific wetland and water storage practices can be placed in that watershed. Then, our second objective is to show that an inventory of practice-placement options can be used to evaluate numeric watershed planning goals to increase water storage and wetland areas that are appropriate for the landscape. Third, we show that the site-specific data can be used to determine whether recruitment of highly ranked sites for implementation may be required to achieve those planning goals.

Flood mitigation may become an important driver for watershed improvement projects emphasizing use of impoundments and wetlands. However, wetland habitat provides benefits for watershed restoration by supporting biodiversity and a wide range of ecosystem services (Erwin 2009; Gleason et al. 2011). Because watershed planning goals can include water storage and wetland habitat, both goals are considered herein without prioritizing one over the other. A case study from southwest Minnesota is used to illustrate these planning concepts, relative to interim (10-year) goals for implementation.

\section{Planning Context in Minnesota's Yellow Medicine River (YMR) Watershed}

During the last decade, Minnesota has transitioned from county-specific water management planning to a watershed approach (BWSR 2019). Under Minnesota's watershed approach, called One Watershed One Plan (1W1P), goals are being set at the river-basin scale that can be achieved along an interim, 10-year timeline, using conservation practices considered appropriate at this broad scale. However, the diversity of landforms across a river basin make it difficult to translate general plans to site-specific conservation alternatives that can be directly used by planners and watershed stakeholders. An approach to make this translation is needed, and planners in Minnesota are turning to the ACPF to meet this need.The US Hydrologic Unit Code (HUC) watershed addressing system, a nested system for watershed identification (USGS 1987), is important here. The ACPF is designed for use at the HUC12 watershed scale (nominally 4,000 to 16,000 ha), whereas river basin plans are being written at the HUC8 scale. The small HUC12 watershed scale is appropriate for planning because it facilitates a local focus that helps residents and landowners identify and form connections with local communities and landscapes, enhancing sustainability outcomes (Atwell et al. 2009). 
Our case study is focused on the Yellow Medicine River (YMR), a HUC8 watershed and a major tributary to the Minnesota River, draining approximately 269,145 ha of land (figure 1). The YMR is centrally located in the Prairie Pothole Region of the north-central United States and dominated by agricultural land cover (79\%). Extensive drainage of the region's fertile, marshy soils enabled agricultural development by European settlers. Today, the region exhibits flashy hydrology and frequent flooding, in part a consequence of draining the landscape (MPCA 2016; Lenhart et al. 2018; Schottler et al. 2013). The climate is also shifting to an increasing frequency of high intensity rain events (Hatfield et al. 2013; Lenhart et al. 2011; Renton et al. 2015). In this context, wetland creation and restorations are options being considered to mitigate peak flows (YMR 1W1P 2016).

Within the YMR watershed, landscapes vary from hummocky glacial moraines in southwest headwater areas, to more level glacial-fluvial plains in the basin's lower, northeastern landscapes (figure 1). In planning efforts, theYMR basin has been divided into four distinct management regions (figure 1), which, from south to north include the following:

1. The Coteau, a plateau exhibiting hummocky glacial deposits that are part of the Des Moines Lobe terminal moraine, which were left along a ridge of Cretaceous shale that was not overridden by Wisconsinan glaciation (approximately 12,000 years ago);

2. A Transitional landscape that grades from the moraine deposits in the south to flatter landscapes in the north;

3. Glaciated Flatland, a glacio-lacustrine plain that formed during glacial retreat; and

4. Minnesota River Floodplain that occupies the flood channel formed by overflow from glacial Lake Agassiz (Fisher 2003), which was subsequently reworked during the middle to late Holocene.

Part of the local context is that conservation efforts to reconnect the Minnesota River to its floodplain by expansion of riparian forests and wet meadows have taken place during the last 25 years through a variety of funding streams and a focus on voluntary conservation. Improvements in channel stability, water quality, and wildlife habitat have been documented (Christensen et al. 2012; Jobe et al. 2018; Yuan et al. 2015).

\section{Figure 1}

Yellow Medicine River watershed and distribution of study watersheds across three distinct landscapes-Coteau, Transitional, and Glaciated Flatland-in the Minnesota River basin. The first $32 \mathrm{~km}$ of the Yellow Medicine River accounts for nearly $81 \%$ of the drop in elevation from the headwaters to the outlet of the watershed with the remaining $19 \%$ in the last $48 \mathrm{~km}$ of the watershed (map adapted from MPCA [2016]).

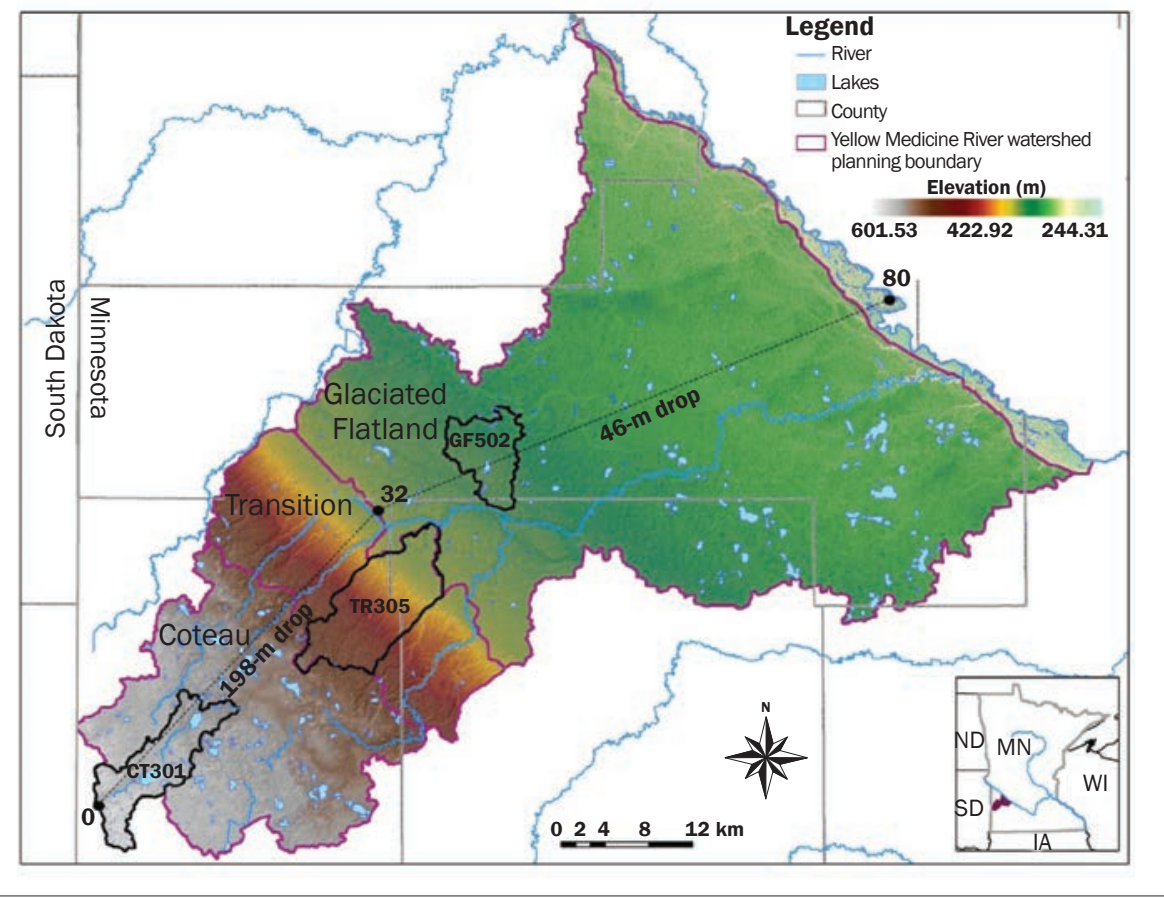

Current goals in the YMR (YMR 1W1P 2016) prioritize efforts in the Coteau, Transitional, and Glaciated Flatland management zones, given recent progress along the Minnesota River floodplain. Specific goals have been set to convert $2 \%$ of cropland to wetlands and install WASCOBs or grassed waterways below $2.5 \%$ of cropland (YMR $1 \mathrm{~W} 1 \mathrm{P}$ 2016). For increased water storage, an interim goal of $1.234 \times 10^{6} \mathrm{~m}^{3}$ (i.e., 1,000 ac-ft) was established basin-wide, but this amounts to $<0.5 \mathrm{~mm}$ depth equivalent across the YMR. For this study, we applied this volume as a hypothetical, 10-year planning goal for each HUC12 watershed in our study. We also focus on establishment of new wetlands and wetland restorations as an interim 10 -year goal (i.e., totaling $2 \%$ of cropland). The YMR 1W1P (2016) includes other goals emphasizing controlled drainage practices and use of winter cover crops, which, while important, are not considered here.

\section{Approach and Methods}

Study Watersheds and ACPF Analyses. We applied the ACPF Version 3.0 (Porter et al. 2018) to one HUC12 watershed in each of three landscapes of the YMR watershed: the
Coteau (HUC 070200040301), Transitional (HUC 070200040305), and Glaciated Flatland (HUC 070200040502) zones (figure 1). Herein, these watersheds are referred to as CT301,TR305, and GF502, respectively.

The ACPF databases for each watershed (Tomer et al. 2017) were downloaded through the ACPF website (www.acpf4watersheds.org). These databases provide data on soil survey, land use, cropping history, and watershed boundaries on a HUC12 watershed basis (Tomer et al. 2017). The Light Detection and Ranging (LiDAR)-derived $3 \mathrm{~m}$ grid DEMs were also downloaded from a database maintained by the state of Minnesota (MnIT 2011). Terrain processing was conducted using ACPF tools, several of which call on TauDEM terrain processing algorithms (Tarboton 1997; Utah State University 2015). This processing removes false impoundments and determines pathways of accumulated overland flow, then the user designates which of those pathways are perennial streams for purposes of riparian assessment. The resulting network of flow paths for each watershed was reviewed to identify perennial streams (following Porter et al. 2018) using shaded-relief topographic 
imagery and 2011 through 2017 color and color infrared aerial photography (MnIT 2019), while considering a state inventory of public waters (MNDNR 2018) and input from local field staff.

Siting Opportunities for Water Detention. The ACPF provides a suite of conservation practice-placement tools that use terrain parameters and field characteristics (pertaining to soils, DEM-derived slope statistics, and land use) to identify suitable sites for in-field, edge-of-field, and riparian practices across the landscape (Porter et al. 2018). This study focused on ACPF results that highlight opportunities to detain water behind impoundments and within topographic depressions (i.e., prairie potholes). The specific tools included for this study were depressions, depression watersheds (to delineate the drainage area above each depression), nutrient removal wetlands, and WASCOBs and WASCOB basins (see Porter et al. [2018] for further details). The ACPF results can be translated to specific conservation practices that are supported by USDA's Natural Resources Conservation Service (NRCS) through federally funded conservation programs. The ACPF's nutrient removal wetlands tool suggests locations for wetland creation, i.e. NRCS Conservation Practice (CP) 658, whereas, the ACPF depressions tool identified sites for wetland restoration (NRCS CP 657) or enhancement (NRCS CP 659). The practice standard identifier for WASCOBs is CP 638 (USDA NRCS 2019).

The ACPF uses differing approaches to site impoundments for WASCOBs and nutrient removal wetlands. The WASCOB practice can be employed in rolling croplands where runoff can accumulate and channelize in broadly concave and gently sloping landscape features. Results of ACPF analyses will often suggest co-located grassed waterways and WASCOBS in these areas; either or both practices may be appropriate depending on the management situation and landowner preferences. The WASCOB tool places an impoundment berm of a user-defined height (within a 1.0 to $4.5 \mathrm{~m}$ range) and of $100 \mathrm{~m}$ length perpendicular to flow paths that have a contributing area ranging from 0.8 to 20 ha. Candidate sites where water can be impounded are retained and tabulated. Multiple sites are tested along each flow path at an interval of $61 \mathrm{~m}$. Essentially, the WASCOB tool evaluates changes in elevation along the simulated impoundment to determine whether there is enough landscape planiform slope curvature (perpendicular to flow path) to install the practice. In this study, $1,1.5$, and $2 \mathrm{~m}$ high impoundments were tested in the three watersheds, with the highest suitable impoundment height retained and tabulated in the results. Impoundments can be installed at sites with planiform relief that is less than twice the impoundment height; this limit avoids suggesting this practice in well-incised terrain, but the range of impoundment heights that can be simulated allows the user flexibility in setting this limit for a given watershed. However, WASCOBs cannot be sited along flow paths where there is $<1 \mathrm{~m}$ of local planiform relief. That is, the criteria are set to reject those locations that are too flat, and others that are too steep. Tests of multiple points along individual flow paths means that multiple WASCOBs may be suggested in series along individual flow paths within agricultural fields, which follows suggested use of the practice (USDA NRCS 2019).

The nutrient removal wetlands tool is used to evaluate sites further downstream, with at least 60 ha of contributing area, down to the watershed outlet, although perennial stream reaches can optionally be selected and excluded by the user. Impoundments of 0.6 to $1.2 \mathrm{~m}$ height (user-selectable, default of $0.9 \mathrm{~m}$ ) are placed at regular intervals (100 to $250 \mathrm{~m}$, user selectable) along flow paths with at least 60 ha, plus an added "buffer height" impoundment of 1 to $1.6 \mathrm{~m}$ (user selectable, default of $1.5 \mathrm{~m}$ ) is also tested. The default selections for the pool and buffer impoundment height, 0.9 and $1.5 \mathrm{~m}$, respectively, were applied and tested at $100 \mathrm{~m}$ intervals along the entire flow network. Site suitability is based on the areas of wetland pool and buffer formed when the DEM is (digitally) filled upslope of the two impoundments. The wetland pool area must be $0.5 \%$ to $2 \%$ of the (minimum 60 ha) contributing area and be at least $25 \%$ of the buffer area (found using the higher impoundment) to be accepted and tabulated in the results. The approach is based on siting criteria for the Iowa Conservation Reserve Enhancement Program (Tomer et al. 2013); results identify sites where a wetland could be installed without impeding tile drainage from croplands in the wetlands drainage area. Some local relief is required for this, and the area-ratio criteria are again designed to reject locations that are either too flat or too steep. For each wetland site that passes the criteria, pool volumes for both the wetland pool and the buffer pool are calculated and tabulated. The buffer pool volume is considered "variable" storage, which the site could provide if the impoundment could include gates to detain runoff up to the larger buffer impoundment height. Candidate wetland sites were reviewed to minimize infrastructure impacts; those sites that overlapped with buildings and major roads were excluded, but sites intersecting township and low maintenance roads were retained in the results. See Porter et al. (2018) for further details.

The depressions and depression-watersheds tools are used to identify natural surface depressions by filling the input DEM and subtracting the input DEM from the filled DEM. After surface depressions are identified, those with $>4,047 \mathrm{~m}^{2}$ surface area, a maximum depth of $0.3 \mathrm{~m}$, and at least $60 \%$ cover of hydric soils were tabulated in the results. These output depressions were considered restorable wetland features and were ranked as described in the next section. The depression watershed tool delineates the drainage basin to each depression, allowing depressions to be ranked by the size of contributing area.

Data Summary and Analyses. The attribute tables for these three water storage practices were exported from ArcGIS for analysis for each HUC12 watershed. Sites tabulated as possible depressional or nutrient removal wetlands were ranked by practice according to volume of water storage (including variable plus permanent storage for nutrient removal wetlands), watershed contributing area, and wetland area (i.e., three separate rankings each in descending order). This required storage volumes within depressions to be calculated from a filled-depth grid that is (optionally) output from the depressions tool, and treated areas above WASCOBs to be calculated using the ArcGIS Watersheds command (Esri 2017). The three rankings represent different approaches to prioritize the largest sites for practice recruitment among landowners. The results were also placed in a random order to represent how a nonprioritized recruitment effort could contribute to planning goals for wetland area and water storage. Because WASCOBS only store water temporarily and are not considered potential wetland features, they were not included in the dual (storage volume, wetland area) rankings.

For each type of practice and in each watershed, watershed contributing area 
was plotted against volume of storage and wetland pool area, with each plotted point representing one site-specific suggested practice location. Plots were compared among practices and watersheds. The next analysis considered nutrient removal wetlands and depressions together, as both practices can provide water storage and wetland habitat benefits together. Upon being ranked according to water volume, pool area, and watershed contributing area, and in random order, results were plotted cumulatively for the first 30 sites to illustrate the effect of ranking approach on water storage and wetland pool area in each watershed. For the purpose of this paper, 30 sites are suggested as a reasonable 10-year implementation goal (three new sites installed per year). These results were compared to 10 -year interim planning goals (i.e., $2 \%$ of cropland in wetland restoration, and $1.234 \times 10^{6} \mathrm{~m}^{3}$ of water storage). Note that assigning the same water storage goal to each HUC12 is equivalent to $19.2 \mathrm{~mm}$ of runoff from CT301, $13.5 \mathrm{~mm}$ from TR305, and $29.6 \mathrm{~mm}$ from GF502. The cumulative total of wetland pool areas and water storage volumes for all sites were also summed for both practices, providing a measure of the landscape's (maximum) capacity to provide these benefits using wetland restoration (depression) and creation (nutrient removal wetland) practices. These potential capacities for water storage volume and wetland pool area were tallied by practice and watershed. Results were mapped by watershed, and landscape distributions of the three practices were compared. The maps illustrate differences in water storage and wetland creation capacities among the YMR's landscape regions.

\section{Results and Discussion}

Differences in landscapes among the three watersheds impact the types and distribution of conservation practices available for water storage and wetland creation (table 1, figure 2). The potential use of WASCOBs, natural depressions, and nutrient removal wetlands to reach watershed planning goals (table 1) also depends on practice design and, in turn, management following installation. One management option could be to control the duration and amount of water detention based on runoff conditions when wet weather threatens to result in flooding. Technology exists to allow remote operation of gates and valves to optimize retention and release

\section{Figure 2}

Map matrix showing distribution of water and sediment control basins (WASCOBs), depressions, and nutrient removal wetlands in the three study watersheds.

СТ301

TR305

GF502

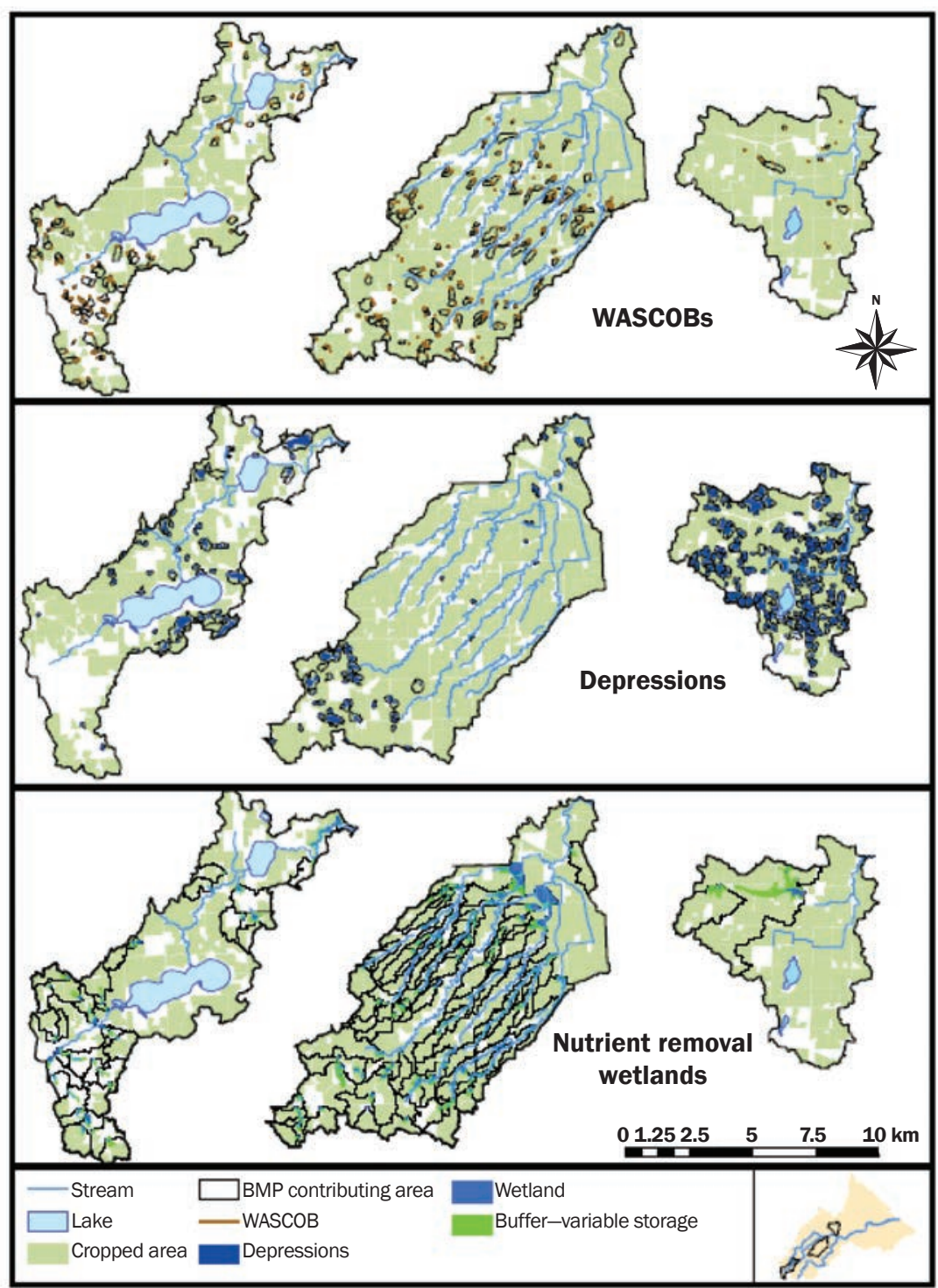

of water (Muschalla et al. 2014). We are not aware of these technologies being employed for runoff attenuation from agricultural landscapes at present, but easements to enable the installation of water storage controls with real-time, remote operation would be possible. Although this would be costly, technology is always becoming more readily available, and the level of investment society is willing to make to mitigate flooding risks (which has included costs to relocate people out of floodprone areas) can change quickly after severe flooding (Di Baldassarre et al. 2013). Smart technologies could become part of watershed management in the future.

We present results separately for each practice below. Figure 2 shows the distribution of each practice in each watershed, and figure 3 shows how the potential storage volume for each practice location may be related to the size of the runoff contributing area, by practice and watershed.

Water and Sediment Control Basins. The rolling terrain of the CT301 and TR305 watersheds provide opportunities to site around 200 WASCOBs in each of these two 


\section{Table 1}

Summary of interim (10-year) planning goals and Agricultural Conservation Planning Framework (ACPF) conservation practice siting results for three HUC12 watersheds. Landscape capacities for water storage volumes and wetland pool areas are totals summed across practices in each watershed. Pool areas are not reported for water and sediment control basins (WASCOBs) because pools are temporary and do not create wetland habitat.

\begin{tabular}{|c|c|c|c|c|}
\hline Characteristic & Unit & ст301 & TR305 & GF502 \\
\hline Total watershed area & ha & 6,443 & 9,143 & 4,171 \\
\hline Area of cropland & ha & 3,413 & 7,018 & 3,350 \\
\hline Area of lakes and ponds & ha & 542 & 0 & 57 \\
\hline \multicolumn{5}{|l|}{ Watershed planning goals (10-year) } \\
\hline Water storage goal (assume 1,000 ac-ft)* & $\mathrm{m}^{3} \times 10^{6}$ & 1.234 & 1.234 & 1.234 \\
\hline Wetland area goal ( $2 \%$ of cropland)* & ha & 68.3 & 140.4 & 67.0 \\
\hline \multicolumn{5}{|l|}{ Counts of ACPF practice placements } \\
\hline WASCOBS & count & 196 & 215 & 20 \\
\hline Depressions & count & 55 & 63 & 216 \\
\hline Nutrient removal wetlands & count & 37 & 125 & 2 \\
\hline \multicolumn{5}{|l|}{ Potential water storage volumes } \\
\hline WASCOBs & $\mathrm{m}^{3} \times 10^{6}$ & 0.348 & 0.325 & 0.081 \\
\hline Depressions & $\mathrm{m}^{3} \times 10^{6}$ & 1.962 & 1.084 & 3.238 \\
\hline $\begin{array}{l}\text { Nutrient removal wetlands } \\
\text { (including variable storage) }\end{array}$ & $\mathrm{m}^{3} \times 10^{6}$ & 3.268 & 9.868 & 1.224 \\
\hline Total water storage-landscape capacity* & $\mathrm{m}^{3} \times 10^{6}$ & 5.577 & 11.277 & 4.542 \\
\hline \multicolumn{5}{|l|}{ Potential wetland pool areas } \\
\hline Depressions & ha & 119.2 & 99.7 & 408.6 \\
\hline Nutrient removal wetlands & ha & 229.8 & 642.7 & 121.7 \\
\hline Total wetland area-landscape capacity* & ha & 349.0 & 742.5 & 530.3 \\
\hline \multicolumn{5}{|l|}{$\begin{array}{l}\text { Watershed area draining to ACPF-proposed } \\
\text { practice locations }\end{array}$} \\
\hline WASCOBS & ha & 434.3 & 658.6 & 81.7 \\
\hline Depressions & ha & 473.1 & 334.6 & $1,129.9$ \\
\hline Nutrient removal wetlands & ha & $6,418.9$ & $7,536.1$ & 140.7 \\
\hline Watershed area that drains to $\geq 1$ practice & ha & $6,418.9$ & $7,598.0$ & $2,210.7$ \\
\hline
\end{tabular}

* "Benchmark" values of landscape capacities and watershed planning goals; see figure 4.

watersheds, an order of magnitude more than observed for the flatter landscape of the GF502 watershed (table 1). One advantage of WASCOBs is that little land is removed from production, which makes them readily acceptable to farmers. However, among the three watersheds, WASCOBs would provide at most $28 \%$ of a $1.234 \times 10^{6} \mathrm{~m}^{3}$ water storage goal, but would only intercept runoff from a fraction $(<7.4 \%)$ of each watershed's area (table 1). In comparison, Rundhaug et al. (2018) found WASCOBs could detain runoff from $14.1 \%$ to $16.5 \%$ of the eastern Iowa watersheds, based on ACPF results for $1.5 \mathrm{~m}$ impoundments. Water storage capacities of WASCOBs are relatively independent of contributing area (figure 3 ).

Nutrient Removal Wetlands. For nutrient removal wetlands, there was substantial variation in the numbers of siting opportunities
In CT301, one wetland site could be installed just above the watershed outlet (treating nearly all the watershed area; see table 1). However, most nutrient removal wetland sites in CT301 were identified in upper reaches, above two lakes in the central part of the watershed. These lakes are much larger than the suggested wetland pools, therefore, these upper wetland sites would be unlikely to significantly attenuate runoff hydrographs at the watershed's outlet (i.e., the lakes themselves should already dampen runoff hydrographs from the upper watershed). This would also apply to water storage practices sited above a smaller lake in GF502 (all depressions). In the uppermost watershed area of CT301, several wetland sites have been implemented, and cropland has been converted to conservation cover during the last 20 years to address water quality in these local lakes. As a result, Lake Shaokatan (i.e., the larger lake in CT301) was removed from Minnesota's list of impaired waters (as required under Section 303[d] of the US Clean Water Act) in 2018 (USEPA 2018).

Nutrient removal wetlands include a permanent wetland pool area and a buffer area that provides for free drainage of contributing area croplands (Porter et al. 2018). Our calculations assume the normal pool elevation for wetland area but add the "variable storage" pool formed by raising the impoundment to the top of the buffer. Leveraging this variable storage capacity for peak flow attenuation would require additional costs and landowner easements, but the feasibility of this could depend on costs and risks of larger structures downstream. Thomas et al. (2016) describe a case study in northern Iowa in which impoundments were designed and installed to achieve both $\mathrm{N}$ removal and runoff attenuation by modifying criteria used to site Conservation Reserve Enhancement Program wetlands in Iowa. The storage volumes estimated by site plot similarly against contributing area in CT301 and TR305 (figure 3), with larger storage volumes estimated with increasing contributing areas.

Depressions. There were nearly four times more locations to detain water in "prairie pothole" depressions in GF502 compared to the upper two watersheds (table 1). As a result, depressions comprise $70 \%$ to $80 \%$ of the potential wetland areas and water storage volumes in GF502, but only $10 \%$ to $35 \%$ in TR305 and CT301 (table 1). Depressions that capture runoff from more than 20 ha 
of watershed contributing area are rare in all three watersheds (figure 3). Potential storage volumes are related to the size of contributing areas for depressions and nutrient removal wetlands, and in a similar way among the three watersheds (figure 3 ). These plots could be used to prioritize among practice locations to favor larger treated areas and storage volumes in each watershed. However, prioritizing based solely on treated area and storage volume may neglect some resource values. Depressions with small contributing areas may only hold water temporarily, but temporary wetland areas are important for some amphibians and migratory waterfowl (Calhoun et al. 2017).

Depressions in cropped fields are drained by surface inlets, with discharge routed to subsurface tile drainage systems. Landowners would have two options to manage a depression to contribute to a watershed's water storage goals: either to continue farming a depression and store water on a temporary basis only, or to create a permanent wetland pool with the option (depending on the site) for detention storage above the normal pool area. The pool areas and storage volumes we calculated (table 1) assume that each depression can be completely filled, and, therefore, suggests a theoretical maximum in terms of wetland area and water storage. Yet many depressions have accumulated sediment from adjacent, upslope croplands; removing this legacy sediment (with site recontouring) could restore water storage capacity and other ecological functions of prairie pothole wetlands. Sediment removal has been used to restore oxbow lakes in the upper Midwest (Schilling et al. 2017)

Use of Results in Planning-Assessing Goals and Landowner Engagement Strategies. This study demonstrates how landscape differences among watersheds affect the relative distribution of practices available for water detention, the total volume of water storage potentially available, and areas of wetland that could be created (table 1, figures 2 and 3). Water storage and wetland pool area data, as summed in table 1 , represent maximum landscape capacities based on LiDAR-measured topography. These values would be modified based on site-specific designs, and could be increased where removal of recently accumulated sediment is part of construction. However, based on the present topography, these estimated landscape capacities still provide context

\section{Figure 3}

Plots of Agricultural Conservation Planning Framework (ACPF) results showing contributing areas and water storage volumes for three conservation practices in three watersheds ([a] CT301, [b] TR305, and [c] GF502). Counts of practices and total storage volumes are given in table 1.

(a)

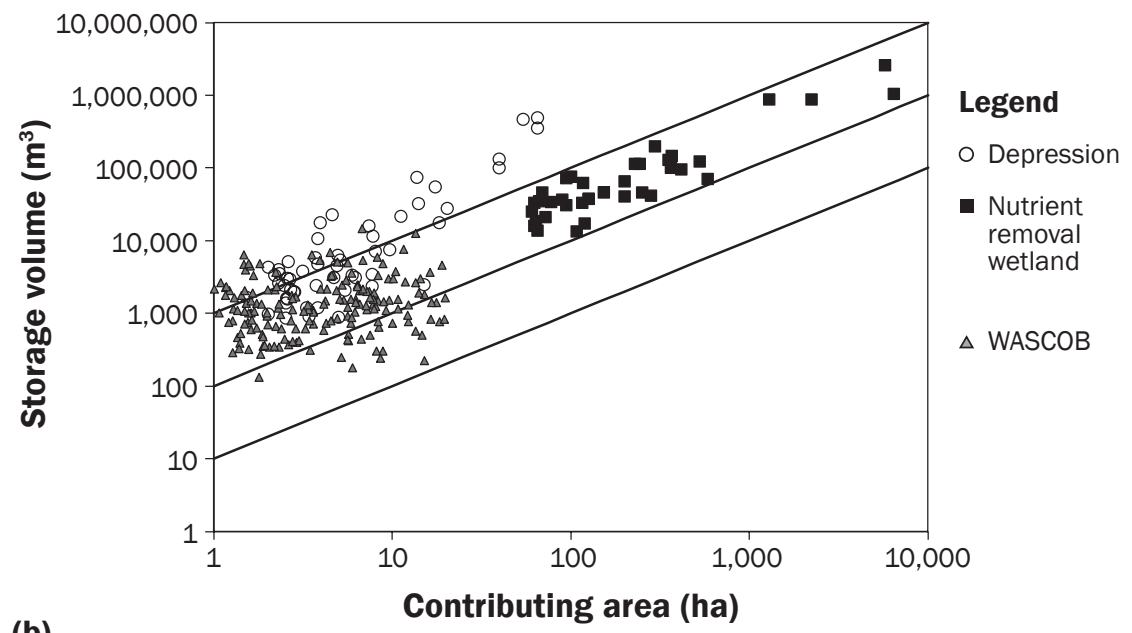

(b)

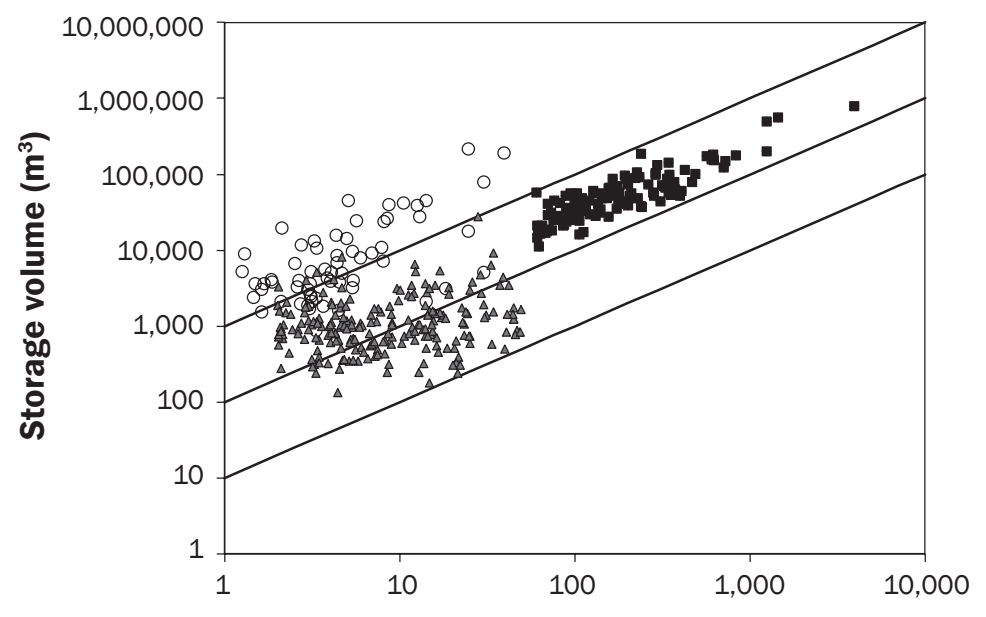

(c)

Contributing area (ha)

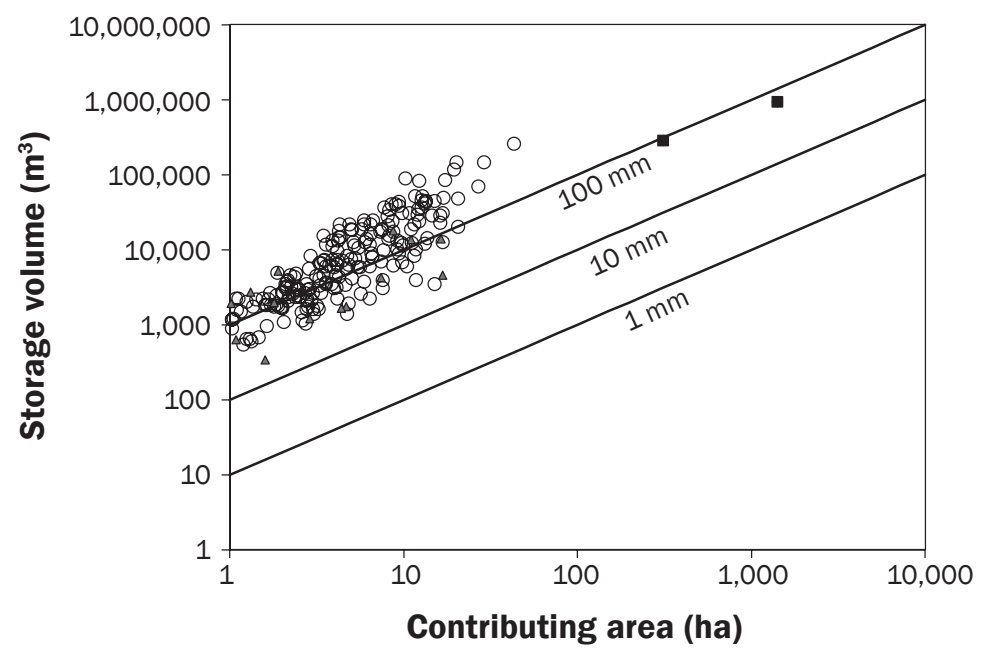


toward establishing and evaluating watershed planning goals. Plots (figure 4) illustrate that landscape capacities to develop water storage and wetland pool areas using depressions and nutrient removal wetlands can be plotted with interim (10-year) watershed planning goals $(2 \%$ of cropland converted to wetlands and $1.234 \times 10^{6} \mathrm{~m}^{3}$ water storage). The plots also illustrate how prioritization strategy can determine whether 30 new practices in a watershed (i.e., 3 per year for 10 years) could approach or attain the interim goals. Results differed among watersheds. We assume that from a social perspective, open enrollment of new practices is preferred. However, the achievement of planning goals may require a targeted approach aimed to enroll sites with larger water storage capacities and/or greater wetland areas. Sites with a larger footprint are more costly to implement, and may be especially challenging where multiple fields and landowners must be recruited to participate in implementing a single wetland practice. How implementation strategy impacts rates of adoption and the pace of progress toward planning goals is an open research question.

We were encouraged to find that a random ranking, simulating an open enrollment approach, could effectively reach (or approach) at least one interim watershed planning goal in all three watersheds (figure 4). The best prioritization approach, though, depends on the watershed and which specific planning goal is most important. In CT301, watershed planning goals are $19 \%$ to $22 \%$ of the watershed capacities for wetland creation and water storage. Enrolling 30 new practices at random could reasonably approach both watershed goals (figure $4 \mathrm{a}$ ), although a prioritized strategy to enroll larger sites should allow both goals to be exceeded. In TR 305, enrolling 30 randomly selected sites could allow water storage goals to be met, but not the wetland creation goal (figure $3 \mathrm{~b}$ ). A strategy targeting large wetland sites with high storage capacities is necessary to meet both goals. Conversely, in GF502, the only two nutrient removal wetlands sites identified essentially must be targeted for implementation in order to reach the water storage goal. However, wetland restorations in 30 randomly selected depression sites could readily approach the goal of establishing new wetlands on $2 \%$ of cropland in the watershed. We note the water storage goal for GF502 is $>25 \%$ of the estimated landscape capacity available using these wetland practices,

\section{Figure 4}

Plots showing watershed planning goals and landscape capacities (denoted "benchmarks," see table 1) for wetland pool areas and water storage volumes using depressions and nutrient removal wetlands in three watersheds ([a] CT301, [b] TR305, and [c] GF502). Prioritization strategies affect progress toward planning goals differently in the three watersheds, as plotted through 30 practice implementations. Goals are met where cumulative practice benefits plot above and/or right of the watershed planning goal (detailed in inset plots, which have identical scales).

(a)

(b)
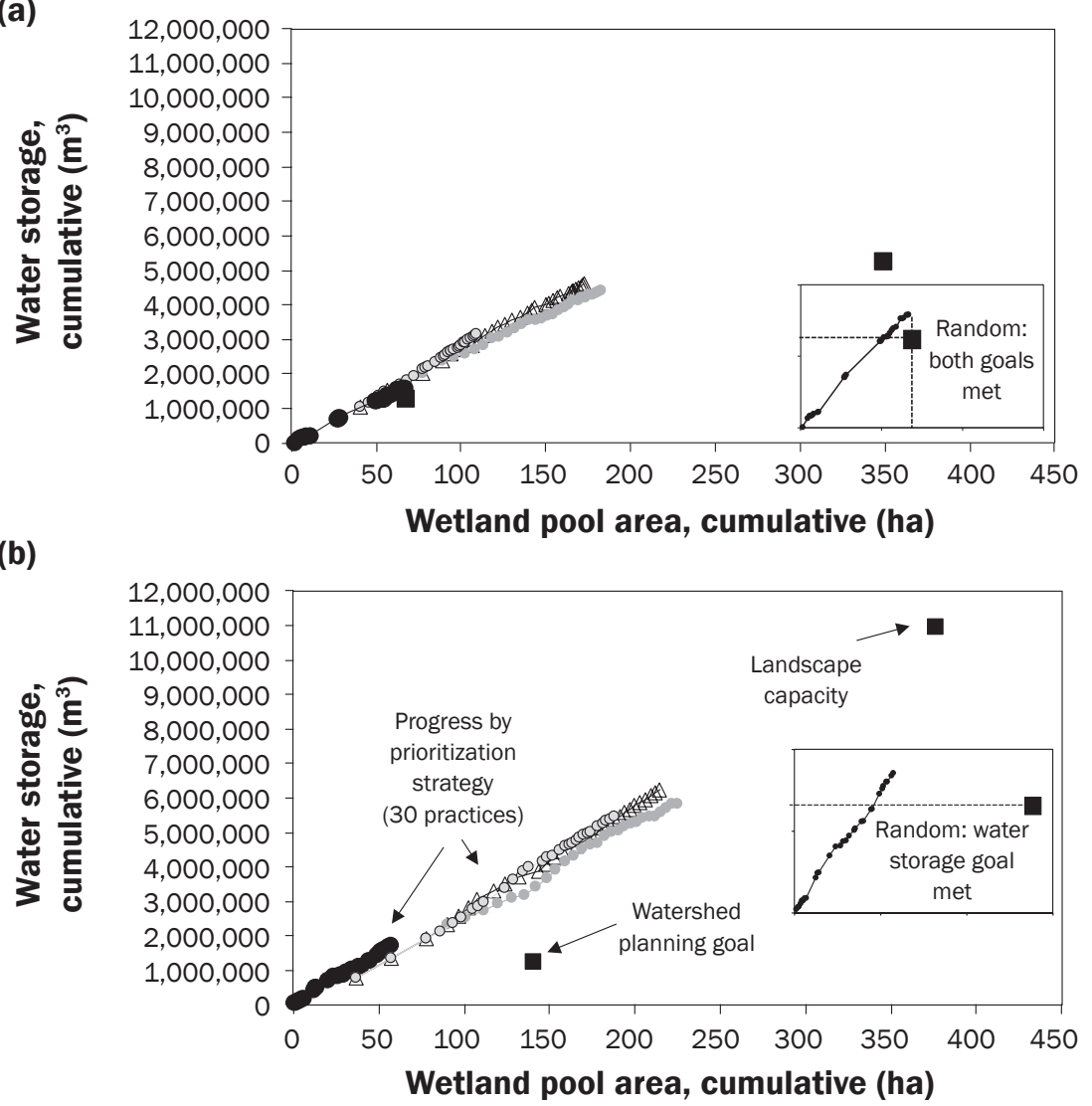

(c)

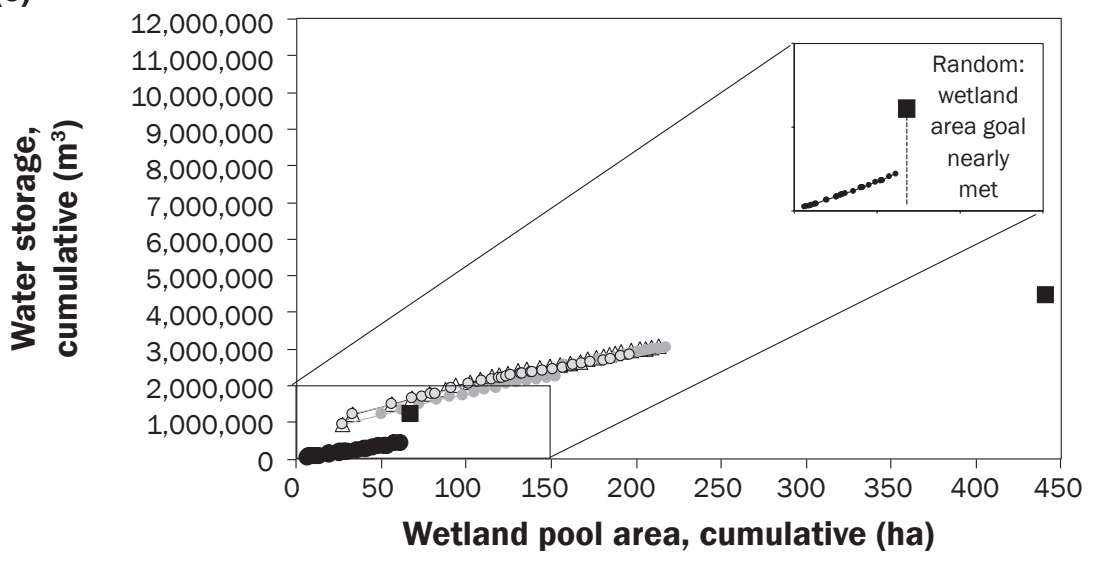

Legend

Prioritization strategy-30 practices sorted by:

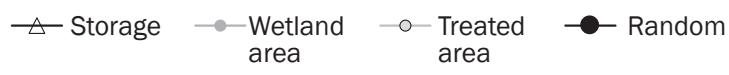

Landscape capacity and planning goal benchmarks 
which may not be realistic for a 10 -year interim in this watershed. The total storage capacity of 30 randomly selected practices in GF502 was nearly $0.441 \times 10^{6} \mathrm{~m}^{3}$ of water storage (figure 4), equivalent to $10.6 \mathrm{~mm}$ of runoff from GF502. Given that GF502 is the smallest and flattest of the three watersheds, $10.6 \mathrm{~mm}$ of storage may be a more realistic storage goal, compared to 19.2 and 13.5 $\mathrm{mm}$ of runoff that $1.234 \times 10^{6} \mathrm{~m}^{3}(1,000$ ac-ft) represents in more sloping landscapes of CT301 and TR305 (respectively), which have a wider diversity of storage practices to select from (table 1).

Certainly, in an actual planning context, water storage or wetland creation goals should not be assigned uniformly among HUC12 watersheds within a basin. Landscape data on conservation capacities provide context to enable interim goals to be considered realistically. The diversity and size of available practices can be considered a priori in setting these goals, utilizing results of ACPF analyses. For example, the random ranking of practices favored small sites in the lower two watersheds, where at least 188 locations could be converted to wetland practices. Whereas, in the upper watershed (CT301), randomized rankings of 30 practices consistently identified several large sites because there were fewer total wetland sites identified in this more steeply rolling terrain (92 total in table 1). These results give examples of how the concept of landscape capacity, based on site-specific data developed across a watershed, can be useful in evaluating conservation planning goals, and how the prioritization approach used in recruitment may influence the chance of success in reaching those goals.

Recent years have seen strong trends toward integrated resource management, which considers multiple resources and includes multiple stakeholders in planning, and adaptive management, which encourages iterative measures as new information and monitoring data become available. Use of these concepts enable planners to deal with the complexities and uncertainties of environmental management while considering social inputs and constraints, but success has often been mixed (Medema et al. 2008). More specific data on conservation options and the potential roles of specific practices for each watershed could enable improved outcomes for watershed management that is based on consultative and adaptive planning approaches.

\section{Conclusion}

Watershed planning involves the balancing of linked resource concerns, and relative tradeoffs and prioritization among those concerns, considering social and economic benefits. Prioritizing among resource concerns requires local input, but must also consider wider issues, particularly with downstream flooding concerns and coincident social costs that are accompanying the shift to a wetter climate (MPCA 2017). These complexities can be better addressed by utilizing new planning technologies that can inform adaptive approaches to watershed planning and social engagement to expand agricultural conservation. Here, we have illustrated a concept that measured landscape capacities for conservation practice benefits of water storage and wetland creation that can be used to evaluate specific watershed planning goals. We have also shown that the prioritization strategy used to enroll new practices can affect success in reaching these linked conservation benefits in different ways. The benefits of targeting a few large sites to most readily meet goals must be balanced against the benefits of open enrollment considering logistics and social perspectives. Because each planning situation is unique, site-specific data can help planners consider planning goals and implementation approaches. Approaches to include economics (Zimmerman et al. 2019) and social benefits should be pursued in order to further prioritize watersheds and opportunities for implementation. We encourage researchers in social and conservation sciences to explore this concept of utilizing landscape data to improve planning and implementation outcomes.

\section{Disclaimer}

Mention of trade names or commercial products in this publication is solely for the purpose of providing specific information and does not imply recommendation or endorsement by the US Department of Agriculture (USDA).

\section{Acknowledgements}

We thank the Yellow Medicine River Watershed District and partnering county and Soil and Water Conservation District staff for discussions on conservation practices, design specifications, and key watershed concerns of local decision-makers. The Minnesota Board of Water and Soil Resources (BWSR) administered the grant to perform the initial targeted watershed analysis across the entire Yellow Medicine River watershed and guidance for local watershed planning, with a special thanks to Matt Drewitz (measures and outcomes coordinator, Board of Soil and Water Resources, Mankato, Minnesota) for his efforts to coalesce several ongoing watershed projects to better inform conservation decisions. The Water Resources Center at Minnesota State
University, Mankato, assisted with hydromodification of digital elevation models. David James, geographic information specialist with the USDA Agricultural Research Service (ARS) National Laboratory for Agriculture and Environment (NLAE) in Ames, Iowa, provided advice on calculating values of water storage and treated areas. Thanks also to Sarah Porter and Jessica Van Horn (Beasley), formerly with the USDA ARS NLAE in Ames, Iowa; Sarah for her critical contributions to the development of the ACPF toolbox, and Jessica for her skillful assistance with cartography during early stages of this project. Development of the Agricultural Conservation Planning Framework was supported by a USDA interagency agreement between the Agricultural Research Service and the Natural Resources Conservation Service. USDA is an equal opportunity provider and employer.

\section{References}

Atwell, R.C., L.A. Schulte, and L.M. Westphal. 2009. Landscape, community, countryside: Linking biophysical and social scales in U.S. Corn Belt agricultural landscapes. Landscape Ecology 24(6):791-806.

Ayalew, T.B., W.F. Krajewski, and R. Mantilla. 2015. Insights into expected changes in regulated flood frequencies due to spatial configuration of flood retention ponds. Journal of Hydrologic Engineering 20(10):04015010.

Ayalew, T.B., W.F. Krajewski, R. Mantilla, D.B. Wright, and S.J. Small. 2017. Effect of spatially distributed small dams on flood frequency: Insights from the Soap Creek Watershed. Journal of Hydrologic Engineering 22(7):04017011.

Babbar-Sebens, M., R.C. Barr, L.P. Tedesco, and M. Anderson. 2013. Spatial identification and optimization of upland wetlands in agricultural watersheds. Ecological Engineering 52:130-142.

BWSR (Board of Soil andWater Resources).2019.OneWatershed One Plan. St. Paul, MN: Board of Soil and Water Resources. https://bwsr.state.mn.us/one-watershed-one-plan.

Calhoun,A.J.K., D.M. Mushet, K.P.Bell,D. Boix,J.A. Fitzsimons, and F. Isselin-Nondedeu. 2017. Temporary wetlands: Challenges and solutions to conserving a 'disappearing' ecosystem. Biological Conservation 211:3-11.

Christensen, V.G., K.E. Lee, J.M. McLees, and S.L. Niemla. 2012. Relations between retired agricultural land, water quality, and aquatic-community health, Minnesota River Basin. Journal of Environmental Quality 41:1459-1472.

Dakota County SWCD (Soil and Water Conservation District). 2016. Subwatershed analysis for Trout Brook, Dakota County, MN. Farmington, MN: Dakota County SWCD. http://www.dakotaswcd.org/pdfs/Trout $\% 20$ Brook\%20SWA.pdf.

Di Baldassarre, G., A. Viglione, G. Carr, K. Kuil, J.L. Salinas, and G. Blŏschl. 2013. Socio-hydrology: Conceptualizing human-flood interactions. Hydrology and Earth System Sciences 17:3295-3303

Environmental Law and Policy Center. 2019. High risk levees along the Upper Mississippi River as identified by the United States Army Corps of Engineers. Chicago, IL: Environmental Law and Policy Center. http://elpc. org/high-risk-levees-mississippi-river/. 
Erwin, K.L. 2009. Wetlands and global climate change: The role of wetland restoration in a changing world. Wetlands Ecology and Management 17(1):71-84.

Esri. 2017. ArcGIS products and support. Redlands, CA: Esri. https://www.esri.com.

Fisher, T.G. 2003. Chronology of glacial Lake Agassiz meltwater routed to the Gulf of Mexico. Quaternary Research 59(2):271-276.

Gesch, K., A. Kiel, T. Sutphin, and R. Wolf. 2020. Integrating farmer input and Agricultural Conservation Planning Framework results to develop watershed plans in Iowa. Journal of Soil and Water Conservation, doi:10.2489/ jswc.2020.0226A

Gleason, R.A., N.H. Euliss Jr., B.A. Tangen, M.K. Laubhan, and B.A. Browne. 2011. USDA conservation program and practice effects on wetland ecosystem services in the Prairie Pothole Region. Ecological Applications 21(3):S65-S81.

Hatfield, J.L., R.M. Cruse, and M.D. Tomer. 2013. Convergence of agricultural intensification and climate change in the Midwestern United States: Implications for soil and water conservation. Marine and Freshwater Research 64:423-435.

Heine, R.A., and N. Pinter. 2012. Levee effects upon flood levels: An empirical assessment. Hydrological Processes 26:3225-3240.

Jobe,A.,A. Kalra, and E. Ibenhdal. 2018. Conservation Reserve Program effects on floodplain land cover management. Journal of Environmental Management 214:305-314.

Karlen, D.L., D.L. Dinnes, M.D. Tomer, D.W. Meek, C.A. Cambardella, and T.B. Moorman. 2009. Is no-tillage enough? A field-scale watershed assessment of conservation effects. Electronic Journal of Integrative Biosciences 7(2):1-24.

Lenhart, C.F., D.J. Smith, A. Lewandowski, P. Belmont, L. Gunderson, and J.L. Neiber. 2018. Assessment of stream restoration for reduction of sediment in a large agricultural watershed. Journal of Water Resources Planning and Management 144(7).

Lenhart, C.F., E.S. Verry, K.N. Brooks, and J.A. Magner. 2011. Adjustment of prairie pothole streams to land-use, drainage and climate changes and consequences for turbidity impairment. River Research and Applications 28(10).

McAllister, L.S., B.E. Peniston, S.G. Leibowitz, B.Abbruzzese, and J.B. Hyman. 2000. A synoptic assessment for prioritizing wetland restoration efforts to optimize flood attenuation. Wetlands 20(1):70-83.

Medema, W., B.S. McIntosh, and P.J. Jeffrey. 2008. From premise to practice:A critical assessment of integrated water resources management and adaptive management approaches in the water sector. Ecology and Society 13(2):29.

MNDNR (Minnesota Department of Natural Resources). 2018. Buffer Protection Map, Minnesota. St. Paul, MN: Minnesota Department of Natural Resources. http:// arcgis.dnr.state.mn.us/gis/buffersviewer/.

MnIT (Minnesota Information Technology, Minnesota Geospatial Information Office). 2011. MnTOPO. Minnesota Geospatial REST Service. St. Paul, MN:
Minnesota Information Technology. http://arcgis.dnr. state.mn.us/maps/mntopo/.

MnIT. 2019. Minnesota Geospatial REST Service. St. Paul MN: Minnesota Information Technology. https://www. mngeo.state.mn.us/index.html.

MPCA (Minnesota Pollution Control Agency). 2016. Yellow Medicine River and surrounding direct Minnesota River tributaries, Watershed Restoration and Protection Strategies. St. Paul, MN: Minnesota Pollution Control Agency. https://ymrwd.org/Restoration\%20and\%20 Protection\%20Strategies.pdf.

MPCA. 2017. Adapting to Climate Change in Minnesota: 2017 Report of the Interagency Climate Adaptation Team. St. Paul, MN: Minnesota Pollution Control Agency. https://www.pca.state.mn.us/sites/default/ files/p-gen4-07c.pdf.

Muschalla, D., B.Vallet, F. Anctil, P. Lessard, G. Pelletier, and P.A Vanrolleghem. 2014.Ecohydraulic-driven real-time control of stormwater basins. Journal of Hydrology 511:82-91.

Opperman, J.J., G.E. Galloway, J. Fargione, J.F. Mount, B.D Richter, and S. Secchi. 2009. Sustainable floodplains through large-scale reconnection to rivers. Science 326:1487-1488.

Porter, S.A., M.D. Tomer, D.E. James, and J.D. Van Horn. 2018. Agricultural Conservation Planning Framework ArcGIS Toolbox User's Manual Version 3.0. https:// acpf4watersheds.org/.

Ranjan, P., A.S. Singh, M.D. Tomer, A.M. Lewandowski, and L.S. Prokopy. 2020. Farmer engagement using a precision approach to watershed-scale conservation planning: What do we know? Journal of Soil and Water Conservation, doi:10.2489/jswc.2020.00072.

Renton, D.A., D.M. Mushet, and E.S. DeKeyser. 2015 Climate change and prairie pothole wetlandsMitigating water-level and hydroperiod effects through upland management: Scientific Investigations Report 2015-5004. Reston,VA: US Geological Survey.

Rundhaug, T.J., G.R. Geimer, C.W. Drake, A.A. Amado, A.A. Bradley, C.F. Wolter, and L.J. Weber. 2018. Agricultural conservation practices in Iowa watersheds: Comparing actual implementation with practice potential. Environmental Monitoring and Assessment 190: 659.

Schilling, K.E., K. Kult, K. Wilke, M. Streeter, and J. Vogelgesang. 2017. Nitrate reduction in a reconstructed floodplain oxbow fed by tile drainage. Ecological Engineering 102:98-107.

Schottler, S.P., J. Ulrich, P. Belmont, R. Moore, J.W. Lauer, D.R. Engstrom, and J.E. Almedinger. 2013. Twentieth century agricultural drainage creates more erosive rivers. Hydrological Processes 28(4), doi:10.1002/hyp.9738.

Tarboton, D.G. 1997. A new method for the determination of flow directions and upslope areas in grid digital elevation models. Water Resources Research 33(2):309-319.

Thomas, N.W., A.A. Amado, K.E. Schilling, and L.J. Weber. 2016. Evaluating the efficacy of distributed detention structures to reduce downstream flooding under variable rainfall, antecedent soil, and structural storage conditions. Advances in Water Resources 96:74-87.
Tomer, M.D., D.E. James, and C.M.J. Sandoval-Green. 2017. Agricultural Conservation Planning Framework: 3. Land use and field boundary database development and structure. Journal of Environmental Quality 46(3):676-686.

Tomer, M.D.,D.W.Meek, and L.A. Kramer. 2005.Agricultural practices influence flow regimes of headwater streams in western Iowa. Journal of Environmental Quality 34(5):1547-1558

Tomer, M.D., S.A. Porter, K.M.B. Boomer, D.E. James, J.A. Kostel, M.J. Helmers, T.M. Isenhart, and E. McLellan. 2015. Agricultural Conservation Planning Framework: 1. Developing multipractice watershed planning scenarios and assessing nutrient reduction potential. Journal of Environmental Quality 44(3):754-767.

Tomer, M.D., S.A. Porter, D.E.James, K.M.B. Boomer,J.A. Kostel, and E. McLellan. 2013. Combining precision conservation technologies into a flexible framework to facilitate agricultural watershed planning. Journal of Soil and Water Conservation 68(5):113-120, doi:10.2489/jswc.68.113A.

US Congress. 2019. House Resolution 2157, Additional Supplemental Appropriations for Disaster Relief Act, 2019. https://www.congress.gov/bill/116th-congress/ house-bill/2157/text

USDA NRCS (Natural Resources Conservation Service). 2019. National Conservation Practice Standards. Washington, DC: USDA Natural Resources Conservation Service. https://www.nrcs.usda.gov/wps/ portal/nrcs/main/national/technical/cp/ncps/.

USEPA (US Environmental Protection Agency). 2018. Nonpoint Source Success Story: Implementation Improves Water Quality in Lake Shaokatan. EPA 841-F-18-001KK (Fact Sheet).Washington, DC: US Environmental Protection Agency. https://www.epa.gov/sites/production/files/201811/documents/mn_shaokatan_1700_508.pdf.

USGS (US Geological Survey). 1987. Hydrologic Unit Maps. Water Supply Paper 2294 (Revised in 2007). Reston, VA: US Geological Survey. https://pubs.usgs. gov/wsp/wsp2294/.

Utah State University. 2015. TauDEM Version 5. Logan, UT: David Tarboton Hydrology Research Group, Utah State University. http://hydrology.usu.edu/taudem/taudem5/.

YMR 1W1P (Yellow Medicine River Watershed One Plan Partnership). 2016. Yellow Medicine River One Watershed One Plan, 2017-2026. Marshall, MN: Yellow Medicine River Watershed One Plan Partnership. https://ymrwd.org/Yellow\%20Medicine \%20 1W1P\%2010_06_2016.pdf.

Yuan, F., M. Mitchell, B. Bohks, K. Mullen, and C. Smith. 2015. Long-term land use and land cover changes affected by the Conservation Reserve Program in the Minnesota River Valley. Journal of Geography and Geology 7(2):105-116.

Zimmerman, E.K., J.C. Tyndall, and L.A. Schultz. 2019 Using spatially targeted conservation to evaluate nitrogen reduction and economic opportunities for best management practice placement in agricultural landscapes. Environmental Management 64:313-328. 